\title{
Effects of Red and Green Glassworts (Salicornia herbacea L.) on Physicochemical and Textural Properties of Reduced-salt Cooked Sausages
}

\author{
Hyun-Wook Kim, Ko-Eun Hwang, Dong-Heon Song, Yong-Jae Kim, Youn-Kyung Ham, In-Jun Yeo, \\ Tae-Jun Jeong, Yun-Sang Choi, and Cheon-Jei Kim* \\ Department of Food Science and Biotechnology of Animal Resources, Konkuk University, Seoul 143-701, Korea
}

\begin{abstract}
This study was conducted to determine the effects of red and green glasswort on the physicochemical and textural properties of reduced-salt cooked sausages. The control was formulated with $1.5 \% \mathrm{NaCl}$; then, three reduced-salt treatments were prepared, with $0.75 \% \mathrm{NaCl}(\mathrm{RS}), 0.75 \% \mathrm{NaCl}+1.0 \%$ red glasswort (RSR) and $0.75 \% \mathrm{NaCl}+1.0 \%$ green glasswort (RSG), respectively. The addition of glasswort within the added amount of $1 \%$ had no influence on the pH value of the reduced-salt cooked sausages, regardless of the glasswort type. In terms of color, RSG treatment conveyed a higher hue angle value than the RSR treatment $(p<0.05)$. Increases in the protein solubility (total and myofibrillar proteins) and apparent viscosity of reduced-salt meat batter that were due to the addition of glasswort were observed; however, there were no differences according to the type of glasswort $(p>0.05)$. Furthermore, the addition of glasswort, regardless of its type, resulted in decreased cooking loss, and increased emulsion stability. As a result, reduced-salt cooked sausages formulated with either red or green glasswort demonstrated similar textural properties to those of the control. In conclusion, the type of glasswort within an added amount of $1 \%$ had no influence on the physicochemical and textural properties of reduced-salt cooked sausages, except for the color characteristics. In terms of color alteration by the addition of glasswort, the red glasswort, which in comparison with the green glasswort could minimize the color changes of reduced-salt cooked sausages, might be an effective source for manufacturing meat products.
\end{abstract}

Keywords: cooked sausage, glasswort, reduced-salt

\section{Introduction}

Sodium chloride $(\mathrm{NaCl})$ is basically one of the essential additives for manufacturing comminuted meat products; moreover, it generally contributes to the formation of the products' sensory characteristics, such as salty taste, and textural properties (Collins, 1997). However, numerous researchers are attempting to reduce the added amount of $\mathrm{NaCl}$ in meat products because previous studies have revealed that excessive sodium intake is greatly related to health risks, such as high blood pressure (Grobbee, 1994) and cardiovascular diseases (Strazzullo et al., 2009). Among various methods to reduce the sodium amount in meat products (considering consumer preferences about natural

\footnotetext{
*Corresponding author: Cheon Jei Kim, Department of Food science and Biotechnology of Animal Resources, Konkuk University, Seoul 143-701, Korea. Tel: +82-2-450-3684, Fax: +822-444-6695, E-mail: kimcj@konkuk.ac.kr
}

sources), the application of various natural ingredients, including seaweeds, have been carried out in order to develop low-salt meat products (Jiménez-Colmenero et al., 2010; López-López et al., 2009). Jiménze-Colmenero et al. (2010) suggested the possibility of partial replacements of pork back fat and $\mathrm{NaCl}$ with edible seaweeds, and konjac glucomannan for low-fat, low-salt frankfurters. According to Cofrades et al. (2008), brown seaweed could improve the water and fat binding properties of low-salt emulsion systems due to the dietary fiber and protein within the seaweed. Recently, Kim et al. (2014) reported that glasswort powder could improve the cooking yield and textural properties of frankfurters due to the salt and dietary fiber contained in the glasswort; moreover, they suggested that a frankfurter formulated with $0.75 \% \mathrm{NaCl}$ and $1.5 \%$ glasswort conveyed a similar texture compared to that prepared with $1.5 \% \mathrm{NaCl}$.

Glasswort (Salicornia herbacea L.), referred to as Hamcho in Korea, is an annual native halophyte in the west 
and south coasts as well as around salt farms in Korea (Song et al., 2007). In Korea, domestic uses of glasswort are increasing as types of globulus and powder due to reports of possible physiological benefits of glasswort. Bang et al. (2002) indicated that 5\% glasswort supplementation resulted in an antidiabetic effect in streptozotocin-induced diabetic rats due to the inhibitory effect of total cholesterol and sugar in the blood. In addition, Cho et al. (2008) suggested that the ingestion of glasswort contributed to the improvement of bowel function, thus relieving constipation. Furthermore, Han and Kim (2003) reported the antioxidant activity of glasswort, and concluded that $10 \%$ glasswort has a similar antioxidant effect to $1 \% \alpha$-tocopherol. In terms of the nutritional value, glasswort contains essential amino acids and fatty acids, dietary fiber as well as a great quantity of minerals, such as sodium $(\mathrm{Na})$, potassium $(\mathrm{K})$, calcium $(\mathrm{Ca})$ and magnesium (Mg) (Min et al., 2002). Recently, for the above reasons, applicability researches of glasswort as a functional ingredient has been attempted in several foods, such as makgeolli (Jeon et al., 2010), sponge cake (An et al., 2010), soybean dasik (Kim and Hong, 2011), steamed rice cake (Lee and Kim, 2013) and tofu (Kim et al., 2010).

In previous studies, the physicochemical properties and composition of glasswort were considerably affected by its part such as leaf and root (Min et al., 2002) and the drying method (Kim and Lee, 2009). Naturally, in addition, the color characteristics of glasswort depend on the harvest season; in particular, the color is conspicuously converted from green to red (Lee and An, 2002) in the month of October in Korea. From the point of view of developing functional meat products, the impacts of functional ingredients on the flavor, texture and color of muscle foods are important considerations for the effective use of functional ingredients (Decker and Park, 2010). Currently, there is no relevant information regarding the differences in the physicochemical characteristics between red and green glassworts. Furthermore, the different physicochemical properties, including the color characteristics of glasswort, at each harvest season are expected to affect the marked differences in the quality characteristics of meat products.

Therefore, the objectives of this study were to determine the effects of red and green glassworts on the physicochemical and textural properties of reduced-sodium cooked sausages as well as to provide effective uses of glasswort as a natural and functional ingredient in meat products.

\section{Materials and Methods}

\section{Preparation of red and green glasswort powders}

Freeze-dried red and green glasswort powder, which was prepared with all parts of the glasswort including the root, stem and leaf, was purchased from a local market. Green glasswort was harvested in Sinan in August 2013, and red glasswort was harvested at the same farm in November 2013. The $\mathrm{pH}$ value, instrumental color, mineral composition, and total dietary fiber content of the freeze-dried red and green glasswort powder are shown in Table 1. The $\mathrm{pH}$ values of freeze-dried glasswort powder was determined using a pH meter (Model 340, MettlerToledo $\mathrm{GmbH}$, Switzerland), and the instrumental color was determined using a colorimeter (Minolta Chroma meter CR-210, Japan). Major mineral elements ( $\mathrm{Na}, \mathrm{K}$, $\mathrm{Ca}$, and $\mathrm{Mg}$ ) were analyzed with atomic absorption spectrophotometry method (Optima 30000 XL, Perkin Elmer) described by Rupérez (2002), the total dietary fiber content was determined with the modified AOAC enzymaticgravimetric method (AOAC, 1995), as described by Choi et al. (2009).

\section{Preparation of reduced-salt cooked sausages}

Fresh pork hams (Musculus Biceps femoris, M. Semitendinosus, and M. Semimembranosus) and pork back fat were purchased from a local processor at post-mortem 48 h. All subcutaneous and inter-muscular fat and visible connective tissue were removed from the ham muscles. Lean meat and back fat were ground though 8-mm plate using a meat grinder (PM-70, Mainca, Spain). Reducedsodium cooked sausages were produced with the formulation are given in Table 2 . The control was formulated with $1.5 \% \mathrm{NaCl}$, and reduced-sodium treatment (RS) were formulated with $0.75 \% \mathrm{NaCl}$. And two additional

Table 1. Physicochemical composition and properties of freezedried red and green glassworts

\begin{tabular}{|c|c|c|c|}
\hline \multirow[b]{2}{*}{ Traits } & \multicolumn{2}{|c|}{ Type of glassworts } & \multirow{2}{*}{$\begin{array}{c}\text { Significance } \\
\text { of } t \text {-test }{ }^{1)}\end{array}$} \\
\hline & $\begin{array}{l}\text { Green } \\
(n=3)\end{array}$ & $\begin{array}{c}\text { Red } \\
(n=3)\end{array}$ & \\
\hline $\mathrm{pH}$ value & 5.26 & 5.79 & $* * *$ \\
\hline CIE L* (lightness) & 72.10 & 61.43 & $* * *$ \\
\hline CIE a* (redness) & -3.11 & 0.76 & $* * *$ \\
\hline CIE b* (yellowness) & 16.42 & 17.01 & $* * *$ \\
\hline Sodium (g/100 g) & 8.927 & 8.097 & $* * *$ \\
\hline Potassium (g/100 g) & 0.963 & 1.313 & $* * *$ \\
\hline Calcium (g/100 g) & 0.573 & 0.833 & $* * *$ \\
\hline Magnesium (g/100 g) & 0.570 & 0.497 & * \\
\hline Total dietary fiber (g/100 g) & 54.00 & 69.24 & $* * *$ \\
\hline
\end{tabular}


Table 2. Formulation of reduced-salt cooked sausages (g/100 g)

\begin{tabular}{ccccc}
\hline \hline \multirow{2}{*}{ Ingredients } & Control & \multicolumn{3}{c}{ Reduced-sodium } \\
treatments & \\
\cline { 2 - 5 } & & RS & RSG & RSR \\
\hline Pork meat & 60 & 60 & 60 & 60 \\
Pork back fat & 20 & 20 & 20 & 20 \\
Ice & 20 & 20 & 20 & 20 \\
Total & 100 & 100 & 100 & 100 \\
NaCl & 1.5 & 0.75 & 0.75 & 0.75 \\
Green glasswort powder & - & - & 1.0 & - \\
Red glasswort powder & - & - & - & 1.0 \\
Sodium nitrite & 0.012 & 0.012 & 0.012 & 0.012 \\
Sodium tri-polyphosphate & 0.3 & 0.3 & 0.3 & 0.3 \\
Ascorbic acid & 0.05 & 0.05 & 0.05 & 0.05 \\
\hline
\end{tabular}

${ }^{1)}$ Control, cooked sausages formulated with $1.5 \% \mathrm{NaCl}$; RS, reduced-salt cooked sausages formulated with $0.75 \% \mathrm{NaCl}$; RSG, reduced-salt cooked sausages formulated with $0.75 \% \mathrm{NaCl}$ and $1.0 \%$ green glasswort; RSR, reduced-salt cooked sausages formulated with $0.75 \% \mathrm{NaCl}$ and $1.0 \%$ red glasswort.

reduced-sodium cooked sausages were formulated with $1 \%$ green glasswort powder (RSG) and $1 \%$ red glasswort powder (RSR), respectively. The total weight of each formulation was adjusted with replacement of $\mathrm{NaCl}$ or glasswort powders with an equal amount of water. For each batch $(1.5 \mathrm{~kg})$ of the treatments, meat, fat, ice, and other ingredients were emulsified by using a bowl cutter ( $\mathrm{Nr}-$ 963009, Scharfen, Germany). After emulsification, all batters were stuffed into collagen casings (\#240, NIPPI Inc., Japan; approximate $25 \mathrm{~mm}$ diameter) by using a stuffer (IS-8, Italy). The sausages were cooked at $80^{\circ} \mathrm{C}$ until the core temperature of $75^{\circ} \mathrm{C}$. After cooling, the cooked sausages were used to analyze physicochemical and textural properties on the manufacturing day.

\section{pH measurements}

The $\mathrm{pH}$ values of cooked samples were determined with a $\mathrm{pH}$ meter (Model 340, Mettler-Toledo GmbH, Switzerland). The $\mathrm{pH}$ values of samples were measured by blending a $5 \mathrm{~g}$ sample with $45 \mathrm{~mL}$ distilled water for $60 \mathrm{~s}$ in a homogenizer at 8,000 rpm (Ultra-Turrax SK15, Janke \& Kunkel, Germany).

\section{Instrumental color evaluation}

Instrumental color were determined using a colorimeter (Minolta Chroma meter CR-210, Japan; calibrated with a white plate, CIE $\mathrm{L}^{*}=+97.83$, CIE $\mathrm{a}^{*}=-0.43$, CIE $b^{*}=$ +1.98 ), equipped with a $25 \mathrm{~mm}$ aperture. The setting for the illuminant was $\mathrm{C}$ illuminant source and the observer was standard $2^{\circ}$. The cross-section of each cooked sausages was taken. CIE L* (lightness), CIE a* (redness), and CIE $b^{*}$ (yellowness) values were recorded. Hue angle were calculated using the following expression;

Hue angle $=\tan ^{-1}\left(\mathrm{~b}^{*} / \mathrm{a}^{*}\right)$.

\section{Total, sarcoplasmic, and myofibrillar proteins solu- bility}

Protein solubility was determined using the modification of method of Joo et al. (1999). Sarcoplasmic protein solubility was determined by dissolving $2 \mathrm{~g}$ of raw meat emulsion in $20 \mathrm{~mL}$ of ice-cold $25 \mathrm{mM}$ potassium phosphate buffer ( $\mathrm{pH}$ 7.2). The samples and buffer were homogenized on ice homogenizer (Model AM-7, Nihonseiki Kaisha Ltd., Japan) and were left to stand on a shaker at $4^{\circ} \mathrm{C}$ overnight. The mixtures were centrifuged at $1500 \mathrm{~g}$ for $20 \mathrm{~min}$ and the protein concentrations of the supernatants determined using the Biuret method (Gornall et al., 1949). Total protein solubility was determined by homogenizing $2 \mathrm{~g}$ of meat emulsion in $20 \mathrm{~mL}$ of ice-cold 1.1 $\mathrm{mol} / \mathrm{L}$ potassium iodide in $100 \mathrm{~mol} / \mathrm{L}$ phosphate buffer $(\mathrm{pH}$ 7.2). The procedures for homogenization, shaking, centrifugation, and protein determination were as described above. Myofibrillar protein solubility was obtained by calculating the difference between total and sarcoplasmic protein solubility.

\section{Cooking loss}

As mentioned above, all treatments were cooked using smokehouse at $80^{\circ} \mathrm{C}$ until the targeted core temperature reached $75^{\circ} \mathrm{C}$. The cooking loss of cooked sausages was determined by calculating the difference in weight after and before cooking as follows;

Cooking loss $(\%)=$ [weight of sausage before cooking (g) - weight of sausage after cooking (g)] / weight of sausage before cooking $(\mathrm{g}) \times 100$

\section{Emulsion stability}

The emulsion stability was determined using the method of Bloukas and Honikel (1992) described by Choi et al. (2010). At the middle of a 15 mesh sieve, pre-weighed graduated glass tubes were filled with meat emulsion. The glass tubes were closed and heated in a $75^{\circ} \mathrm{C}$ water bath for $30 \mathrm{~min}$. After cooling to approximately $4^{\circ} \mathrm{C}$, to facilitate fat and water layer separation, the fat and water releases in the bottom of each tube were measured.

Water release $(\%)=$ [the water layer $(\mathrm{mL}) /$ weight of raw meat emulsion $(\mathrm{g})] \times 100$

Fat release $(\%)=[$ the fat layer $(\mathrm{mL}) /$ weight of raw 
meat emulsion $(\mathrm{g})] \times 100$

\section{Apparent viscosity}

Apparent viscosity of meat emulsion was measured in triplicate with a rotational viscometer (HAKKE Viscotester $^{\circledR}$ 550, Thermo Electron Corporation, Germany) at 10 rpm. The standard cylinder sensor (SV-2) was positioned in a $25 \mathrm{~mL}$ metal cup filled with batter and allowed to rotate under a constant shear rate $\left(\mathrm{s}^{1}\right)$ for $60 \mathrm{~s}$ before each reading was taken. The temperature of each sample at the time $\left(18 \pm 1^{\circ} \mathrm{C}\right)$ of testing was also recorded (Choi et al., 2010).

\section{Texture profile analysis (TPA)}

Texture profile analysis was performed at room temperature with a texture analyzer (TA-XT2i, Stable Micro Systems Ltd., Surrey, England). The cooked samples under abovementioned condition were cooled to room temperature at $25^{\circ} \mathrm{C}$ for $3 \mathrm{~h}$. Before analysis, the cooked sausages were allowed to equilibrate to room temperature. Samples were taken from the central portion of each cooked sausage. The conditions of texture analysis were as follows: pre-test speed $2.0 \mathrm{~mm} / \mathrm{s}$, post-test speed $5.0 \mathrm{~mm} / \mathrm{s}$, maximum load $2 \mathrm{~kg}$, head speed $2.0 \mathrm{~mm} / \mathrm{s}$, distance $8.0 \mathrm{~mm}$, force $5 \mathrm{~g}$. Value for hardness $(\mathrm{kg})$, springiness (ratio), cohesiveness, gumminess $(\mathrm{kg})$, and chewiness $(\mathrm{kg})$ were determined as described by Bourne (1978).

\section{Statistical analysis}

All tests were done at least three times for each experimental condition and mean values were reported. The obtained results of physicochemical composition and properties of red and green glasswort were statistically processed, and significance of difference between means ( $t$ test) was determined. Among cooked sausage treatments, an analysis of variance were also performed on all the variables measured using the general linear model (GLM) procedure of the SAS statistical package (2008). Duncan's multiple range test $(p<0.05)$ was used to determine differences between treatment means.

\section{Results and Discussion}

\section{pH value and color characteristics of reduced-salt cooked sausages}

The effect of glasswort type on the $\mathrm{pH}$ value and color characteristics of reduced-salt cooked sausages is presented in Table 3. The $\mathrm{pH}$ values of reduced-salt cooked sausages ranged from 6.12 to 6.16 , and the statistical result indicated that there were no significant differences in the $\mathrm{pH}$ value among all treatments $(p>0.05)$. Previously, Lee and Kim (2013) reported that an increase in the added level of glasswort (0-20\%) led to a decreased $\mathrm{pH}$ value of Sulgidduk. In this study, although a significant difference $(p<0.001)$ was observed in the $\mathrm{pH}$ value between red and green glasswort powder (Table 1), the addition of glasswort within the added amount of $1 \%$ had no influence on the $\mathrm{pH}$ value of reduced-salt cooked sausages, regardless of the glasswort type.

The addition of glasswort resulted in decreased CIE L* (lightness) and CIE $\mathrm{a}^{*}$ (redness) values and increased CIE $\mathrm{b}^{*}$ (yellowness) value of reduced-salt cooked sausages. Additionally, the color type of glasswort engendered a different color alternation of reduced-salt cooked sausages. Hence, the RS treatment had a significantly higher lightness than the control $(p<0.05)$. According to Fernández-López et al. (2004), the reduction in $\mathrm{NaCl}$ concentration ranged from 0 to $3 \%$, thereby gradually increasing the lightness of pork meat due to the light reflection associated with the water holding capacity. Red glasswort (RSR treatment) contributed to a lower lightness of reduced-salt cooked sausages compared to the green glasswort (RSG treatment). This result could be related with the darker color of red glasswort compared to that of green

Table 3. Effects of red and green glassworts on $\mathrm{pH}$ value and color characteristics of reduced-salt cooked sausages

\begin{tabular}{|c|c|c|c|c|c|}
\hline \multirow{2}{*}{ Traits } & \multirow{2}{*}{ Control } & \multicolumn{3}{|c|}{ Reduced-salt treatments $^{\mathrm{I}}$} & \multirow{2}{*}{$\mathrm{SEM}^{2)}$} \\
\hline & & RS & RSG & RSR & \\
\hline $\mathrm{pH}$ value & 6.13 & 6.16 & 6.12 & 6.13 & 0.028 \\
\hline CIE L* (lightness) & $72.92^{b}$ & $74.71^{\mathrm{a}}$ & $72.59^{\mathrm{c}}$ & $70.94^{\mathrm{d}}$ & 0.283 \\
\hline CIE a* (redness) & $8.74^{\mathrm{a}}$ & $9.03^{\mathrm{a}}$ & $5.10^{\mathrm{c}}$ & $6.23^{\mathrm{b}}$ & 0.350 \\
\hline CIE b* (yellowness) & $8.39^{\mathrm{c}}$ & $8.31^{\mathrm{c}}$ & $11.35^{\mathrm{b}}$ & $12.69^{\mathrm{a}}$ & 0.398 \\
\hline Hue angle & $43.84^{\mathrm{c}}$ & $42.63^{\mathrm{c}}$ & $65.80^{\mathrm{a}}$ & $63.85^{\mathrm{b}}$ & 2.267 \\
\hline
\end{tabular}

${ }^{1)}$ Control, cooked sausages formulated with $1.5 \% \mathrm{NaCl}$; RS, reduced-salt cooked sausages formulated with $0.75 \% \mathrm{NaCl}$; RSG, reducedsalt cooked sausages formulated with $0.75 \% \mathrm{NaCl}$ and $1.0 \%$ green glasswort; RSR, reduced-salt cooked sausages formulated with $0.75 \%$ $\mathrm{NaCl}$ and $1.0 \%$ red glasswort.

${ }^{2)}$ SEM: standard error of the means.

${ }^{\mathrm{a}-\mathrm{d}}$ Means within a row with different letters among treatments are significantly different $(p<0.05)$. 
glasswort (Table 1). The reduction in $\mathrm{NaCl}$ revealed no change in the redness and yellowness of cooked sausages $(p>0.05)$; however, the addition of glasswort caused a decrease in the redness and an increase in the yellowness of reduced-salt cooked sausages $(p<0.05)$. In particular, reduced-salt cooked sausages formulated with green glasswort (RSG treatment) conveyed a lower redness and yellowness $(p<0.05)$ than those formulated with red glasswort (RSR treatment). For these reasons, RSG treatment resulted in a higher hue angle value, which implies a similar to yellow color than the RSR treatment $(p<0.05)$. In previous studies, the apparent color changes due to the addition of green glasswort were observed in several foods, such as honey cake (Kim and Hong, 2011), tofu (Kim et al., 2010) and sponge cake (An et al., 2010). Additionally, Cofrades et al. (2008) indicated that the color of the low-salt emulsion system was affected by the type and concentration of functional ingredients when meat and pork back were added in equal amounts. Regarding the conversion of glasswort color, according to Liebezeit et al. (1999), Salicornia europaea, which belongs to the same family (Chenopodiaceae) with Salicornia herbacea, has simple pigments such as carotenoids, chlorophyll a chlorophyll b; moreover, carotenoids are responsible for the red discoloration during autumn. Thus, the changes in the color characteristics of reduced-salt cooked sausages formulated with green and red glassworts might be affected by a different composition of color pigment within glassworts.

\section{Protein solubility of reduced-salt meat batters}

Generally, it is well known that protein solubility in comminuted meat products is affected by the $\mathrm{pH}$ value of raw meat, ionic strength, type of salt, fat content, etc. (Gordon and Barbut, 1992; Nayak et al., 1996). The effects of red and green glassworts on protein solubility of reduced-salt meat batters are presented in Fig. 1. The reduction in the added amount of $\mathrm{NaCl}$ resulted in a decrease in total and myofibrillar protein solubility of meat batter $(p<0.05)$, whereas the addition of glasswort, regardless of type, increased the total and myofibrillar protein solubility of reduced-salt meat batters. However, the sarcoplasmic protein solubility of reduced-salt meat batter was not affected by the reduction in $\mathrm{NaCl}$ as well as by the addition of glasswort ( $p>0.05)$. A similar result was observed by Kim et al. (2014), who reported that the addition of green glasswort increased the total and myofibrillar protein solubility and had no influence on the sarcoplasmic protein solubility of meat emulsion prepared

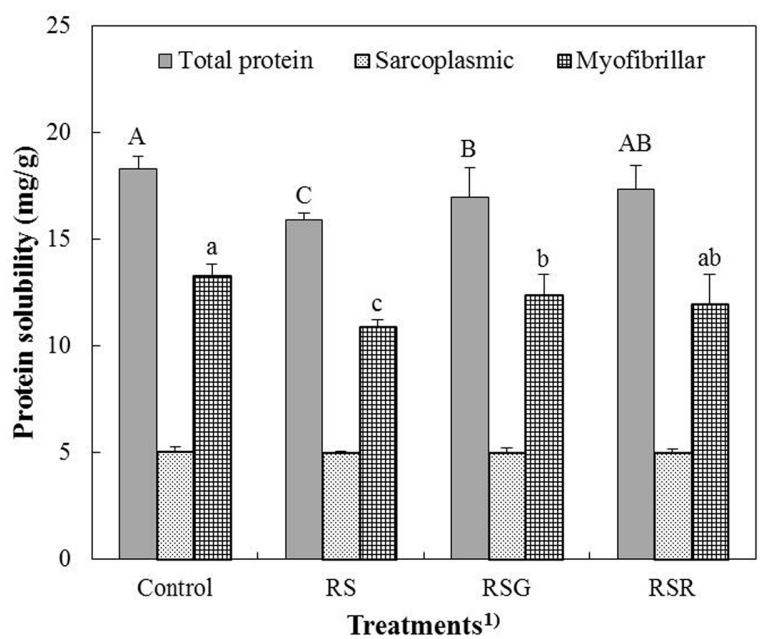

Fig. 1. Effects of red and green glassworts on protein solubility (total, sarcoplasmic, and myofibrillar) of reducedsalt meat batters. ${ }^{1)}$ Treatments: Control, meat batter formulated with $1.5 \% \mathrm{NaCl}$; RS, reduced-salt meat batter formulated with $0.75 \% \mathrm{NaCl}$; RSG, reduced-salt meat batter formulated with $0.75 \% \mathrm{NaCl}$ and $1.0 \%$ green glasswort; RSR, reduced-salt meat batter formulated with $0.75 \% \mathrm{NaCl}$ and $1.0 \%$ red glasswort. Values are Mean \pm S.D. A-C the different letters within total protein solubility are significantly different $(p<0.05)$. a-c the different letters within myofibrillar protein solubility are significantly different $(p<0.05)$.

with $0.75 \% \mathrm{NaCl}$. Interestingly, although there were no significant differences in total and myofibrillar protein solubility of RSG and RSR treatments ( $p>0.05)$, the meat batter formulated with green glasswort had a significantly lower total and myofibrillar protein solubility than those of the control $(p<0.05)$. Basically, myosin, which is one of the major myofibrillar proteins, is differently extracted by lithium $(\mathrm{Li})$, sodium $(\mathrm{Na})$ and potassium $(\mathrm{K})$ ions (Cheung and Cooke, 1971); further, it is well known that the extracting degree of the protein to form meat emulsion differed from monovalent chloride salts and divalent chloride salts (Gordon and Barbut, 1992). According to Nayak et al. (1996), divalent salts, such as $\mathrm{CaCl}_{2}$ and $\mathrm{MgCl}_{2}$, increased the protein solubility at a low concentration $(0.05 \%)$ with $4 \% \mathrm{NaCl}$. In this study, the composition of trace elements, such as $\mathrm{Na}, \mathrm{K}, \mathrm{Mg}$ and $\mathrm{Ca}$, between red glasswort and green glasswort showed considerable differences (Table 1). The green glasswort indicated a higher concentration of $\mathrm{Na}(p<0.001)$ and $\mathrm{Mg}$ $(p<0.05)$ compared to the red glasswort, whereas higher concentrations of $\mathrm{K}$ and $\mathrm{Ca}(p<0.001)$ were observed in the red glasswort. Thus, the increase in the total and myofibrillar protein solubility of meat batter was differently affected by the type of glasswort. Furthermore, a slightly 


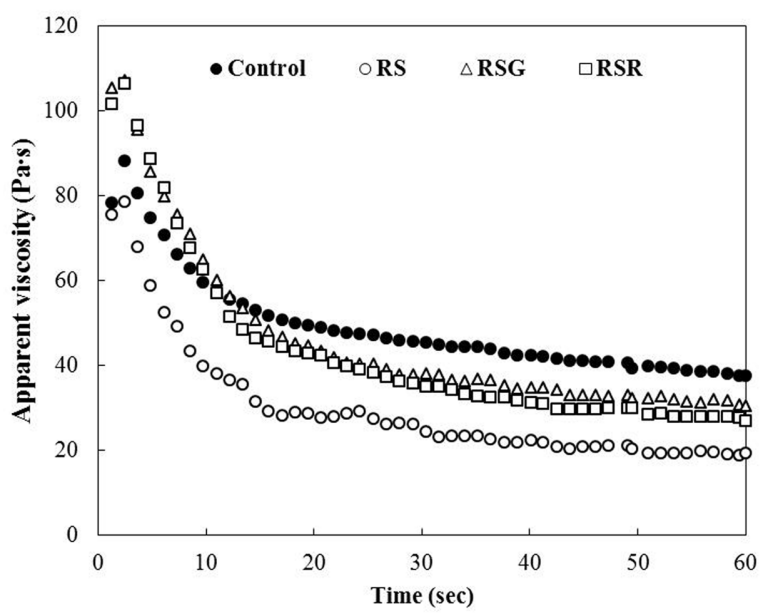

Fig. 2. Changes in apparent viscosity of reduced-sodium meat batters formulated with various red and green glassworts for 60 sec. Control (๑), meat batter formulated with $1.5 \% \mathrm{NaCl}$; RS $(\bigcirc)$, reduced-sodium meat batter formulated with $0.75 \% \mathrm{NaCl}$; RSG $(\triangle)$, reduced-sodium meat batter formulated with $0.75 \% \mathrm{NaCl}$ and $1.0 \%$ green glasswort powder; RSR $(\square)$, reduced-sodium meat batter formulated with $0.75 \% \mathrm{NaCl}$ and $1.0 \%$ red glasswort powder.

lower protein solubility of meat batter formulated with green glasswort might be related to a lower total concentration of divalent ions $(\mathrm{Ca}$ and $\mathrm{Mg})$.

\section{Apparent viscosity}

Generally, the viscosity of comminuted meat batter depicted a pseudoplastic fluid behavior, and the added amounts of fat and water directly influenced the viscosity of comminuted meat batter (Payne and Rizvi, 1988). In addition, the improvement in the viscosity of meat batter contributed to the texture, such as firmness, juiciness and elasticity, of emulsion type sausages (Girard et al., 1990). Fig. 2 presents the effect of red and green glassworts on the changes in the apparent viscosity of reduced-salt meat batter. RS treatment demonstrated an obviously decreased apparent viscosity, and the addition of glasswort, regard- less of the type, increased the apparent viscosity of the reduced-salt meat batter. Likewise, Kim et al. (2014) suggested that the dietary fiber contained in the glasswort is one of the main reasons affecting the increased apparent viscosity due to the addition of glasswort. Recently, dietary fiber, as a functional ingredient, is extensively used to reduce fat and $\mathrm{NaCl}$ of several meat products; moreover, previous reports have indicated that the addition of dietary fiber led to an increase in viscosity due to the water-binding capacity and fat absorption capacity of dietary fiber (Choi et al., 2010; Jiménez-Colmenero et al., 2005). Further, Lee et al. (2008) reported that an increase in the apparent viscosity of meat emulsion depends on the added amount of kimchi powder, which contains a dietary fiber content of 28.32-32.50\%. In Table 1, although there was a significant $(p<0.05)$ difference in the total dietary fiber between the red and green glasswort, however, the different dietary fiber content of the glasswort did not portray a decided influence on the apparent viscosity of the reduced-salt meat batter. Thus, the dietary fiber within the glasswort could be responsible for the increased apparent viscosity of the reduced-salt meat batter, and the viscosity of the reduced-salt meat batter was not affected by the type of glasswort under added amount of $1 \%$.

\section{Cooking loss and emulsion stability}

The effects of red and green glassworts on cooking loss and emulsion stability of reduced-salt cooked sausages are shown in Table 4. As expected, a reduction in the added amount of $\mathrm{NaCl}$ resulted in an obvious increase in the cooking loss of cooked sausages; thus, RS treatment showed the highest cooking loss among all treatments $(p<0.05)$. Although RSG and RSR treatments conveyed a higher cooking loss than the control $(p<0.05)$, the addition of glasswort decreased the cooking loss of reducedsalt cooked sausages regardless of the glasswort type. In previous studies, a reduction in $\mathrm{NaCl}$ caused a decline in protein solubility due to the lower ion strength, thereby

Table 4. Effects of red and green glassworts on cooking loss and emulsion stability of reduced-salt cooked sausages

\begin{tabular}{cccccc}
\hline \hline Traits & \multirow{2}{*}{ Control } & \multicolumn{3}{c}{ Reduced-salt treatments $^{\mathrm{I})}$} & \multirow{2}{*}{ SEM $^{2)}$} \\
\cline { 3 - 5 } & & RS & RSG & RSR & 0.967 \\
Cooking loss (\%) & $5.96^{\mathrm{c}}$ & $16.99^{\mathrm{a}}$ & $10.43^{\mathrm{b}}$ & $2^{\mathrm{b}}$ & \\
Emulsion stability & & & & & \\
Water release (\%) & $2.59^{\mathrm{c}}$ & $13.39^{\mathrm{a}}$ & $8.48^{\mathrm{b}}$ & $7.76^{\mathrm{b}}$ & 1.132 \\
Fat release (\%) & $0.50^{\mathrm{b}}$ & $1.10^{\mathrm{a}}$ & $0.60^{\mathrm{b}}$ & $0.60^{\mathrm{b}}$ & 0.774 \\
\hline
\end{tabular}

${ }^{1)}$ Control, cooked sausages formulated with $1.5 \% \mathrm{NaCl}$; RS, reduced-salt cooked sausages formulated with $0.75 \% \mathrm{NaCl}$; RSG, reducedsalt cooked sausages formulated with $0.75 \% \mathrm{NaCl}$ and $1.0 \%$ green glasswort; RSR, reduced-salt cooked sausages formulated with $0.75 \%$ $\mathrm{NaCl}$ and $1.0 \%$ red glasswort.

${ }^{2}$ SEM: standard error of the means.

${ }^{\mathrm{a}-\mathrm{c}}$ Means within a row with different letters among treatments are significantly different $(p<0.05)$. 
contributing to the failure of the formation of a stable three-dimension matrix structure (Sofos, 1983). Hence, RS treatment showed much higher water and fat releases than the control, and the addition of glasswort, regardless of its type, significantly reduced the water and fat releases $(p<0.05)$. Recently, various attempts are being made in order to overcome the technological problems of directly reducing $\mathrm{NaCl}$ in meat processing. In particular, several natural sources as a non-meat functional ingredient, which contains rich-dietary fiber, have been widely used to develop reduced and/or low salt meat products. Cofrades et al. (2008) indicated that the 5\% addition of edible seaweeds significantly improved the emulsion stability of meat emulsion formulated with $0.5 \% \mathrm{NaCl}$. In addition, they reported that the addition of 5\% Wakame (Undaria pinnatifida) resulted in no released water and fat from the meat emulsion, and suggested that this effect resulted from the enhancement of water- and fat-binding properties due to the dietary fiber and protein contained in the seaweeds. Similarly, Jiménez-Colmenero et al. (2010) reported that dietary fiber in seaweeds $(50 \mathrm{~g} / 100 \mathrm{~g}$ dietary fiber concentration) could be responsible for the cooking loss and emulsion stability of low-fat and low-salt frankfurters (added $1.5 \mathrm{~g} / 100 \mathrm{~g}$ dietary fiber based on total sample weight). In addition, Kim et al. (2014) suggested that the dietary fiber and salts in glassworts is an important factor for improving cooking loss and emulsion stability. Our results are in agreement with the effect of dietary fiber in glassworts; however, the type of glasswort has no influence on both cooking loss and emulsion stability of reduced-sodium frankfurters formulated with $0.75 \% \mathrm{NaCl}$. In Table 1 , the red and green glassworts contain a total dietary fiber content of 54.00 and $69.24 \mathrm{~g} /$ $100 \mathrm{~g}$, respectively. Computatively, the addition of red and green glassworts increases the approximate 0.54-0.69 $\mathrm{g} / 100 \mathrm{~g}$ of dietary fiber in reduced-sodium frankfurters. Although there were significant differences in the mineral composition and total dietary fiber content between red and green glassworts, considering the relatively small proportion of glassworts, the type of glasswort did not affect the cooking loss and emulsion stability of reducedsalt cooked sausages.

\section{Texture profile analysis (TPA)}

Generally, it is well known that a reduction in the added $\mathrm{NaCl}$ causes poor textural properties of comminuted meat products due to a decreased water holding capacity and lower extracting degree of solubilized muscle proteins (Totosaus and Pérez-Chabela, 2009). The effect of glasswort type on the textural properties of reduced-salt cooked sausages is shown in Table 5. The reduced-salt cooked sausages formulated with $0.75 \% \mathrm{NaCl}$ (RS treatment) had a significantly lower hardness, gumminess and chewiness than the control $(p<0.05)$. The addition of glasswort, regardless of its type, increased the hardness, gumminess and chewiness of reduced-salt cooked sausages, in which their textural properties are similar to those of the control $(p>0.05)$. In addition, there were no significant differences in the springiness and cohesiveness among all treatments $(p>0.05)$. According to related studies, Pigott et al. (2000) reported that divalent chloride salt, such as $\mathrm{CaCl}_{2}$ and $\mathrm{MgCl}_{2}$, increased the extraction of total soluble protein, thereby contributing to firmer gel that conveyed a higher peak force. Further, in Jiménez-Colmenero et al. (2010), the dietary fiber contained in seaweed and/or konjac is largely responsible for the increase in the hardness and chewiness of low-fat/reduced-salt frankfurters. According to Farouk et al. (2002), myofibrillar protein, mainly myosin, could contribute to the firmness of cooked sausages with gelation, whereas sarcoplasmic protein could be associated with cohesiveness. In Fig. 1, although the addition of glasswort increased the total and myofibrillar protein solubility, the type of glasswort had no influence on the total, myofibrillar and sarcoplasmic protein solu-

Table 5. Effects of red and green glassworts on textural properties of reduced-salt cooked sausages

\begin{tabular}{|c|c|c|c|c|c|}
\hline \multirow{2}{*}{ Traits } & \multirow{2}{*}{ Control } & \multicolumn{3}{|c|}{ Reduced-salt treatments $^{\mathrm{t})}$} & \multirow{2}{*}{ SEM $^{2)}$} \\
\hline & & $\mathrm{RS}$ & RSG & RSR & \\
\hline Hardness (kg) & $0.42^{\mathrm{a}}$ & $0.33^{\mathrm{b}}$ & $0.41^{\mathrm{a}}$ & $0.41^{\mathrm{a}}$ & 0.007 \\
\hline Springiness (ratio) & 0.87 & 0.86 & 0.88 & 0.89 & 0.003 \\
\hline Cohesiveness & 0.43 & 0.43 & 0.42 & 0.43 & 0.002 \\
\hline Gumminess (kg) & $0.18^{\mathrm{a}}$ & $0.14^{\mathrm{b}}$ & $0.18^{\mathrm{a}}$ & $0.18^{\mathrm{a}}$ & 0.003 \\
\hline Chewiness $(\mathrm{kg})$ & $0.16^{\mathrm{a}}$ & $0.12^{\mathrm{b}}$ & $0.16^{\mathrm{a}}$ & $0.16^{\mathrm{a}}$ & 0.002 \\
\hline
\end{tabular}

${ }^{1)}$ Control, cooked sausages formulated with $1.5 \% \mathrm{NaCl}$; RS, reduced-salt cooked sausages formulated with $0.75 \% \mathrm{NaCl}$; RSG, reducedsalt cooked sausages formulated with $0.75 \% \mathrm{NaCl}$ and $1.0 \%$ green glasswort; RSR, reduced-salt cooked sausages formulated with $0.75 \%$ $\mathrm{NaCl}$ and $1.0 \%$ red glasswort.

${ }^{2)}$ SEM: standard error of the means.

${ }^{a, b}$ Means within a row with different letters among treatments are significantly different $(p<0.05)$. 
bility of meat batter. Also, a similar tendency of apparent viscosity was observed between the reduced-salt meat batter and red and green glassworts. Thus, the increased myofibrillar protein solubility due to the addition of glasswort, regardless of its type, resulted in increases in hardness, gumminess and chewiness of reduced-salt meat batter.

In conclusion, a $1 \%$ addition of both red and green glassworts increased the protein solubility (total and myofibrillar proteins) and apparent viscosity of reduced-salt meat batter formulated with $0.75 \% \mathrm{NaCl}$ due to the salt and dietary fiber contained in each glasswort; hence, it contributes to the reduction in cooking loss and improvement of emulsion stability and textural properties. Despite the differences in the mineral composition and total dietary fiber content, the type of glasswort within an added amount of $1 \%$ had no influence on the physicochemical and textural properties of reduced-salt cooked sausages, except for color characteristics. In terms of color alteration with the addition of glasswort, the red glasswort, which could minimize the color changes of reduced-salt cooked sausages, as compared to the green glasswort is an effective source for manufacturing meat products.

\section{Acknowledgements}

This paper was supported by Konkuk University in 2013.

\section{References}

1. An, H. K., Hong, G. J., and Lee, E. J. (2010) Properties of sponge cake with added saltwort (salicornia herbacea L.). Korean J. Food Culture 25, 47-53.

2. AOAC (1995) Official methods of analysis of AOAC (Vol. 41, 16th ed). Association of Official Analytical Chemists, Washington DC.

3. Bang, M. A., Kim, H. A., and Cho, Y. J. (2002) Hypoglycemic and antioxidant effect of dietary Hamcho powder in streptozotocin-induced diabetic rats. J. Korean Soc. Food Sci. Nutr. 31, 840-846.

4. Bloukas, I. and Honikel, K. O. (1992) The influence of additives on the oxidation of pork back fat and its effect on water and fat binding in finely comminuted batters. Meat Sci. 32, 31-43.

5. Bourne, M. C. (1978) Texture profile analysis. Food Technol. 32, 62-66.

6. Cheung, H. C. and Cooke, R. (1971) Effect of alkali ions on myosin conformation. Biopolymers 10, 523-528.

7. Cho, Y. S., Kim, S. I., and Han, Y. S. (2008) Effects of slander glasswort (salicornia herbacea L.) extract on improvements in bowel function and constipation relief. Korean $J$. Food Sci. Technol. 40, 326-331.
8. Choi, Y. S., Choi, J. H., Han, D. J., Kim, H. Y., Lee, M. A., Kim, H. W., Lee, J. W., Chung, H. J., and Kim, C. J. (2010) Optimization of replacing pork back fat with grape seed oil and rice bran fiber for reduced-fat meat emulsion systems. Meat Sci. 84, 212-218.

9. Choi, Y. S., Choi, J. H., Han, D. J., Kim, Y. H., Lee, M. A., Kim, H. W., Jeong, J. Y., and Kim, C. J. (2009) Characteristics of low-fat meat emulsion systems with pork fat replaced by vegetable oils and rice bran fiber. Meat Sci. 82, 266-271.

10. Cofrades, S., López-López, I., Solas, M. T., Bravo, L., and Jiménez-Colmenero, F. (2008) Influence of different types and proportions of added edible seaweeds on characteristics of low-salt gel/emulsion meat systems. Meat Sci. 79, 767-776.

11. Collins, J. E. (1997) Reducing salt (sodium) levels in processed meat, poultry and fish products. In: Pearson, A. M., and Dutson, T. R. (eds) Advances in meat research series. Chapman \& Hall, London, pp. 282-297.

12. Decker, E. A. and Park, Y. (2010) Healthier meat products as functional foods. Meat Sci. 86, 49-55.

13. Farouk, M. M., Wieliczko, K., Lim, R., Turnwald, S., and MacDonald, G. A. (2002) Cooked sausage batter cohesiveness as affected by sarcoplasmic proteins. Meat Sci. 61, 85-90.

14. Fernández-López, J., Sayas-barberá, E., Pérez-Alvarez, J. A., and Aranda-Catalá, V. (2004) Effect of sodium chloride, sodium tripolyphosphate and $\mathrm{pH}$ on color properties of pork meat. Color Res. Appl. 29, 67-74.

15. Girard, J. P., Culioli, J. Maillard, T., Denoyer, C., and Tourille, C. (1990) Influence of technological parameters on the structure of the batter and the texture of frankfurter type sausages. Meat Sci. 27, 13-28.

16. Gordon, A. and Barbut, S. (1992) Effect of chloride salts on protein extraction and interfacial protein film formation in meat batters. J. Sci. Food Agric. 58, 227-238.

17. Gornall, A. G., Bardawill, C. J., and David, M. M. (1949) Determination of serum proteins by means of the Biuret reaction. J. Biol. Chem. 177, 751-766.

18. Grobbee, D. E. (1994) Sodium and potassium. In: Swales, J. D. (ed) Textbook of hypertension: electrolyte intake and human hypertension. Blackwell Scientific, Oxford, pp. 539-551.

19. Han, S. K. and Kim, S. M. (2003) Antioxidative effect of salicornia herbacea L. grown in closed sea beach. J. Korean Soc. Food Sci. Nutr. 32, 207-210.

20. Jeon, B. Y., Seo, H. N., Yun, A., Lee, I. H., and Park, D. H. (2010) Effect of glasswort (salicornia herbacea L.) on nurukmaking process and makgeolli quality. Food Sci. Biotechnol. 19, 999-1004.

21. Jiménez-Colmenero, F., Ayo, M. J., and Carballo, J. (2005) Physicochemical properties of low sodium frankfurter with added walnut: effect of transglutaminase combined with caseinate, $\mathrm{KCl}$ and dietary fibre as slat replacers. Meat Sci. 69, 781-788.

22. Jiménez-Colmenero, F., Cofrades, S., López-López, I., RuizCapillas, C., Pintado, T., and Solas, M. T. (2010) Technological and sensory characteristics of reduced/low-fat, low-salt frankfurters as affected by the addition of konjac and seaweed. Meat Sci. 84, 356-363.

23. Joo, S. T., Kauffman, R. G., Kim, B. C., and Park, G. B. (1999) 
The relationship of sarcoplasmic and myofibrillar protein solubility to colour and water-holding capacity in porcine longissimus muscle. Meat Sci. 52, 291-297.

24. Kim, H. J. and Lee, J. H. (2009) Physicochemical properties of salicornia herbacea powder as influenced by drying methods. Food Eng. Prog. 13, 105-109.

25. Kim, H. W., Hwang, K. E., Song, D. H., Kim, Y. J., Lim, Y. B., Ham, Y. K., Yeo, E. J., Chang, S. J., Choi, Y. S., and Kim, C. J. (2014) Effect of glasswort (Salicornia herbacea L.) on the texture of frankfurters. Meat Sci. In press.

26. Kim, M. H. and Hong, G. J. (2011) Qualities of soybean dasik with added saltwort (salicornia herbacea L.) powder. Korean J. Food Culture 26, 501-505.

27. Kim, M. H., Shin, M. K., Hong, G. J., Kim, K. S., and Lee, K. A. (2010) Quality assessment of soybean curd supplemented with saltwort (salicornia herbacea L.). Korean J. Food Cookery Sci. 26, 406-412.

28. Lee, J. T. and An, B. J. (2002) Detection of physical activity of salicornia herbacea. Korean J. Herbol. 17, 61-69.

29. Lee, M. A., Han, D. J., Jeong, J. Y., Choi, J. H., Choi, Y. S., Kim, H. Y., Paik, H. D., and Kim, C. J. (2008) Effect of kimchi powder level and drying methods on quality characteristics of breakfast sausage. Meat Sci. 80, 708-714.

30. Lee, Y. J. and Kim, E. H. (2013) Quality characteristics of sulgidduk added with saltwort (salicornia herbacea L.) powder. Korean J. Culinary Res. 19, 203-214.

31. Liebezeit, G., Künnemann, T. D., and Gad, G. (1999) Biotechnological potential of North Sea salt marsh plants-a review of traditional knowledge. J. Biotechnol. 70, 77-84.

32. López-López, I., Cofrades, S., Ruiz-Capillas, C., and JiménezColmenero, F. (2009) Design and nutritional properties of potential functional frankfurters based on lipid formulation, added-seaweed and low salt content. Meat Sci. 83, 255-262.

33. Min, J. G., Lee, D. S., Kim, T. J., Park, J. H., Cho, T. Y., and Park, D. I. (2002) Chemical composition of salicornia herbacea L. J. Food Sci. Nutr. 7, 105-107.

34. Nayak, R., Kenney, P. B., and Slider, S. (1996) Protein extractability of turkey breast and thigh muscle with varying sodium chloride solutions as affected by calcium, magnesium and zinc chloride. J. Food Sci. 61, 1149-1154.

35. Payne, N. N. and Rizvi, S. S. H. (1988) Rheological behavior of comminuted meat batters. J. Food Sci. 53, 70-73.

36. Pigott, R. S., Kenney, P. B., Slider, S., and Head, M. K. (2000) Formulation protocol and dicationic salts affect protein functionality of model system beef batters. J. Food Sci. 65, 11511154.

37. Rupérez, P. (2002) Mineral content of edible marine seaweeds. Food Chem. 79, 23-26.

38. Sofos, J. N. (1983) Effects of reduced salt $(\mathrm{NaCl})$ levels on the stability of frankfurters. J. Food Sci. 48, 1684-1691.

39. Song, H. S., Kim, D. P., Jung, Y. H., and Lee, M. K. (2007) Antioxidant activities of red Hamcho (Salicornia herbacea L.) against lipid peroxidation and the formation of radicals. Korean J. Food Nutr. 20, 150-157.

40. Strazzullo, P., D’Elia, L., Kandala, N. B., and Cappuccio, F. P. (2009) Salt intake, stroke, and cardiovascular disease: metaanalysis of prospective studies. Br. Med. J. 339, b4567.

41. Totosaus, A. and Pérez-Chabela, M. L. (2009) Textural properties and microstructure of low-fat and sodium-reduced meat batters formulated with gellan gum and dicationic salts. LWTFood Sci. Technol. 42, 563-569.

(Received 2014.4.25/Revised 2014.5.27/Accepted 2014.5.29) 